\title{
Environmental Law at the Turn of the Century: A Reportorial Fragment of Contemporary History
}

\author{
Joseph L. Sax $\dagger$
}

TABLE OF CONTENTS

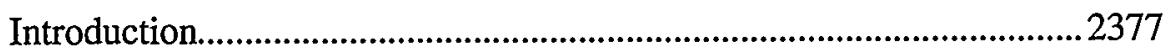

I. The Strategy for Preserving the Endangered Species Act ................2380

II. Key Legal Issues Encountered in Enforcing the Endangered Species Act........................................................................................2382

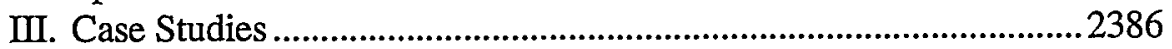

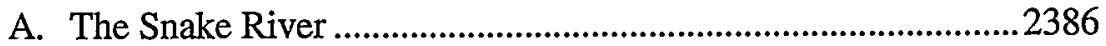

B. The Rio Grande and the Silvery Minnow ....................................2390

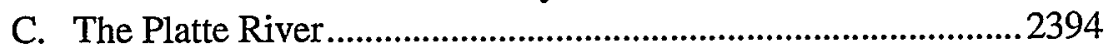

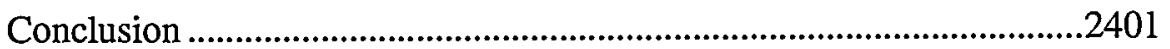

Copyright (C) 2000 Joseph L. Sax. California Law Review, Incorporated (CLR) is a California nonprofit corporation. CLR and the authors are solely responsible for the content of their publications.

$\dagger$ James H. House and Hiram H. Hurd Professor, School of Law, University of California, Berkeley (Boalt Hall). 


\title{
Environmental Law at the Turn of the Century: A Reportorial Fragment of Contemporary History
}

\author{
Joseph L. Sax
}

Contemporary environmental law, focused on biodiversity protection and restoration, is proving especially contentious since it affects virtually all areas, public and private, developed and pristine, unlike an earlier time when some areas were set aside for protection, but elsewhere development was given virtually free rein. The new, broader needs of the biodiversity era have spawned a new style of public control, much more centered on collaborative, contract-like efforts to achieve restoration of natural functions within the developed worlds of agriculture, industry, and urban life. Three exemplary efforts to achieve compliance with the Endangered Species Act in the setting of heavily used rivers in the arid West are illustrative of the new style of environmental management, with all its promise and its problems.

\section{INTRODUCTION}

Environmental law has passed through three stages during this century, all alike in one sense and distinctly different in another. Each phase has been a reaction to the vast appetite of modern society for the products of the natural world. While the extractive and consuming capacities of 1990s industry make the impact of earlier eras' activities seem almost Lilliputian, it is chasteming to recall, as William Cronon has so brilliantly demonstrated, that the ecology of northern New England was irremediably disrupted by settlers several centuries ago; ${ }^{1}$ the beaver was virtually exterminated from the northeast im a few decades; ${ }^{2}$ the vast white pine forests of the upper Great Lakes were denuded before the automobile was even

1. See William Cronon, Changes in the Land: Indians, Colonists, and the Ecology of New England (1983).

2. See Barrett v. State, 116 N.E. 99,100 (N.Y. 1917) (discussing the nearly complete extermination of beavers in New England through trapping). 
invented; ${ }^{3}$ and the assault upon numerous bird species by both market and sports hunters was murderous. ${ }^{4}$

While the problem has been much the same down the years, our responses have changed significantly. The first era of environmental legislation implemented a sort of "enclave" theory of protection. While the normal business of society went on apace in most places, some areas were set aside in protected enclaves, sometimes for their aesthetic value (the early national parks), sometimes for their habitat values (wildlife refuges). The establishment of these reserves was achieved relatively quietly, since the result largely left industry and development to pursue their goals everywhere else. The second stage-pollution control-came much closer to home, and was a great deal more expensive. Pollution control, however, has also accommodated business needs relatively smoothly, at least insofar as it dealt with conceded human health and safety issues, perhaps because, like the enclave strategy, it essentially involved accepting and rationalizing commercial and industrial activity (internalizing externalities), rather than challenging it. ${ }^{5}$

The core of today's environmental law, the emerging era of biodiversity protection and restoration, is proving much more contentious. It cannot be put off to a few remote areas; it reaches everywhere, to private as well as public lands, to developed places and those ready for development, as well as to backcountry areas. It has no relatively clear objective limits, as do efforts to control human health contaminants. It seems to rest on the principle that the more human activity is reduced in favor of natural processes, the better. And it seems to focus not only on protecting what we have, but on restoring previous conditions, thus undoing some undetermined amount of existing development (for example, tearing down dams to restore river flows). In contrast to the goal of earlier eras of environmental protection that were ideologically compatible with the premises of a modern, human-focused and developmentally oriented society, the new biodiversity-oriented environmental movement appears to many to challenge its fundamental premises.

For these reasons, contemporary environmental goals, though they have very broad public support, simultaneously generate a great deal of public uncertainty and unease. Oft repeated in the popular press, and usually formulated by self-interested sources, the familiar questions are nonetheless revealing of a widespread bafflement about where we are, and should be, going: Ought we really try to save every species? Does not all

3. See, for example, the description of a Miehigan lumbering town in BRUCE CATTON, WaItiNG For the MORNING Train: AN AMERICAN BoyhoOd (1972).

4. See Holly Doremus, Restoring Endangered Species: The Importance of Being Wild, 23 HaRv. ENVTL. L. Rev. 1, n.16 (1999).

5. See, e.g., Federal Water Pollution Control Act, 33 U.S.C. §§ 1251-1387 (1998); Clean Air Act, 42 U.S.C. $\S \S 7401-7671 q$ (1998). 
human activity (farming, housing, manufacturing) necessarily diminish biodiversity? Where does the restoration agenda end: Should a place such as the Columbia River basin be restored to its pre-European-settlement condition in order to bring back the salmon?

One of the fascinating things about the way American law and policymaking functions is that it seems quite unresponsive to these, or similarly probing, questions. Instead, it appears content to acknowledge that loss of biodiversity is a serious problem, that it has been undervalued, and that we need somehow to shift our priorities, without knowing (or trying to determine in advance) exactly where these efforts will, or should, end up. The process of change seems to be driven by what might be called the dynamics of possibility-political, economic, and legal-rather than by theory or by response to any coherent legislative mandate.

In the pages that follow, I seek to illustrate this peculiar American process, not exhaustively, but as it has emerged in one particular and controversial (but, I think, characteristic) context. In so doing, I hope to provide a perspective on the evolution of environmental law unlike that portrayed in the standard literature, much of which criticizes the government either for going too far (for example, beyond what science is said to justify) or for doing too little (for example, less than what Congress has mandated). ${ }^{6}$ I suggest that these conventional perspectives can be usefully illuminated by a look at the pragmatic, tactical, down-in-the-trenches drama that is being acted out day by day as the law-in this case, the Endangered Species Act-is implemented. I think it also tells a good deal about how American environmental law inches its way along notably new paths in its own untheoretic, but far from thoughtless, manner.

I predict that biodiversity policy will be the centerpiece of environmental law in the coming decades, and will take shape primarily in response to the pattern and practice of administration I am about to describe. In sketching out the lineaments of this approach, I hope to suggest how, in practice, we accommodate the deep tension between development and preservation, between respect for existing uses and promotion of environmental restoration, in the process finding ways to implement significant priorities whether or not they are formally recognized. To illustrate this process, I have chosen three related case examples of Endangered Species Act enforcement. I believe they are particularly instructive because they deal with the contentious subject of western water rights, and because, as I shall note presently, they raise several extremely troublesome legal issues.

6. The claims on both sides are cited in Holly Doremus, Listing Decisions Under the Endangered Species Act: Why Better Science Isn't Always Better Policy, 75 WASH. U. L.Q. 1029, 1032-33 \& nn.4-8 (1997). 
I

\section{The Strategy for Preserving the Endangered Species AcT ${ }^{7}$}

Although the Endangered Species Act (ESA) had been in place since 1973, it was not until the 1990s that its full potential came to the fore. As increasing numbers of species began to be listed as threatened or endangered in response to litigation by environmental plaintiffs, ${ }^{8}$ the scope of the Act was recognized: in particular, its applicability to habitat on private land and its prohibition of any "take," even of a single exemplar, of a listed species without an approved conservation plan. It became increasingly clear that a crisis of enforcement was in the offing. Water users from rivers with listed species and property owners who found themselves with listed species on their land often encountered frustration. The Fish and Wildlife Service, which administers the Act for most species, was not well organized to operate a permit-granting enterprise. The available permitting device for private activities, the Habitat Conservation Plan (HCP), pursuant to Section 10 of the ESA, ${ }^{9}$ was cumbersome and had been very little used. ${ }^{10}$ It had not been conceived as an expeditious device, suitable to relatively small enterprises or individuals. People who made inquiries about their obligations often found there was no way to get a simple yes or no, even when the answer could have been quite straightforward. An atmosphere of anxiety built up. Farmers began to fear they could not continue to cultivate existing farmland, and landowners worried that their land would become unsalable because of doubt whether it could be built on or even whether improvement work could be done on existing structures. Irrigators were afraid their water supply would be cut off whenever there was a dry year.

The press and property-rights advocates picked up on these anxieties, and political pressures built for legislative revision of the Act, with provisions that would have greatly weakened it. ${ }^{11}$ Though much of the anti-ESA publicity overstated or even misstated the reality, it called to public attention not only a genuine failure of effective administration, but also that the

7. Several of the conclusions and observations in this Part and throughout the Essay are drawn from my personal experience in working on Endangered Species Act issues as Counselor to the Secretary of the Interior from 1994 to 1996.

8. See U.S. Fish and Wildlife Service, Facts About the Endangered Species Act 2 (June/July 1995 rev.) ("The Fish and Wildlife Service is committed to propose for listing about 100 species per year through 1996 under a 1992 court settlement with the Fund for Animals and other environmental groups.").

9. See 16 U.S.C. \$ 1539(a) (1998).

10. Between 1982 (when HCPs were first authorized) and 1992, only 14 HCPs were completed. See Testimony of George T. Frampton, Jr., Assistant Secretary, U.S. Dep't of the Interior, Before the Endangered Species Task Force of the House Resources Committee on the Endangered Species Act 6 (May 25, 1995) (typescript on file with author).

11. See, e.g ., Endangered Species Conservation and Management Act of 1995, H.R. 2275, 104th Cong. (1995). 
ESA had an extraordinary potential to constrain economic activity and that it lacked the discretion or economic practicability tests that characterized most regulatory laws. All these tensions were dramatically sharpened following the congressional elections in November 1994, when the Republicans took over both houses of Congress with an agenda that included a strong property-rights element, heavily focused on the Endangered Species Act and the wetlands regulation provisions of the Clean Water Act. Congressional concern about the ESA was by no means limited to one party in the Congress, and the strategy I am about to describe was developed in the spring of 1994, well before the election.

From the perspective of the Department of the Interior, a new approach was critical to avoid a weakened reauthorization of the ESA. To prevent that result, a two-part strategy was adopted: first, to see that no ESA legislation emerged from the Congress. That was done largely by offering no Administration bill at all, while working with entities such as the Western Governors Association to hammer out a series of mutually acceptable provisions. ${ }^{12}$ While no one ever openly said so, it would be reasonable to conclude that the exercise was largely designed to preempt other legislative drafting efforts, in the expectation that the outcome would be sufficiently bland that it would please neither ESA supporters nor skeptics. That, in any event, was the eventual outcome, and no reauthorized ESA had been enacted as this Essay went to print.

The second part of the strategy, congruent with the no-legislation effort, was both bolder and more interesting. Its goal was to demonstrate that the ESA, as it stood, was both workable (did not have to be revised) and working (was being effectively enforced and was accomplishing species protection). The essential idea was to bring the largely moribund Habitat Conservation Plan program to life, that is, to bring about negotiated solutions to sensitive ESA problems. In that way, legislative pressures for weakening the Act would be abated, litigation challenging it would be avoided, and the regulated parties would in effect be recruited as partners in asserting the Administration's "message": The Act is working, and we are engaged in a common effort with the private sector to make it work.

Nowhere was this more important than in the mountain West, much of it deeply committed to its history of resource exploitation, strongly aligned with mining, grazing, and irrigation interests, and home to a number of the most conservative members of Congress. The essential question was how to bring about acceptable results without either creating resistance that would produce undesired legislative pressures, or litigation that would both delay progress and potentially undermine the legal foundations of the ESA.

12. See Western States Water Council, The Endangered Species Act: Improving Implementation 27 (typescript summarizing the presentation of John Leshy, Solicitor, U.S. Dep't of the Interior, on file with author). 
The greater and lesser successes achieved in that effort are the subject of the illustrative case examples that follow. They provide instructive lessons in the opportunities and perils in seeking to shift an entrenched developmental economy to one in which biodiversity values, both in maintenance and restoration, are sought to be given a high priority while respecting the importance of the region's traditional economy.

\section{II}

\section{KEY LEGAL ISSUES ENCOUNTERED IN ENFORCING THE ENDANGERED SPECIES ACT}

One factor that impedes making a transition from one set of societal priorities to another is the embodiment of settled expectations in law, in particular in various versions of property and related rights. While such rights are always malleable to some degree in a dynamic social system, they inevitably shape the process of transition from one set of values to another. The interplay of forces that occurs when a rooted economic system encounters new environmental claims provides an instructive instance of the way this process unfolds. Change occurs against the background of claims of legal right.

Enforcement of the ESA raises three significant legal claims in the setting of western water rights. One consequence is that ESA/water cases pose an unappealing context for the government to litigate its regulatory prerogatives as it seeks to shift water from traditional diversionary uses, such as irrigation, to instream species protection. The prototype situation is this: Under a long-standing and essentially unqualified contract with an irrigation district, the Bureau of Reclamation ("Reclamation") delivers water for irrigation from a federal reservoir. During normal years, as a result of diversions by the farmers, stretches of the river dry up, or flows are sharply reduced. Those stretches are critical habitat for a listed species of fish under the ESA. ${ }^{13} \mathrm{~A}$ biological opinion requires certain flows to be available during the summer to avoid jeopardy. If contract rights are to be fulfilled and conventional operation of the reservoir maintained, there simply is not enough water to avoid jeopardy without "shorting" the irrigators. ${ }^{14}$ What to do? ${ }^{15}$

Certainly, many regulatory laws change the nature of preexisting property rights, such as contractual rights between private parties. As the

13. See Endangered Species Act, 16 U.S.C. $§ 1533(b)(6)(C)$ (1998).

14. Depending on the particular circumstances, the problem can arise either under section 7 or section 9 of the ESA, $i d$. $\S \$ 1536(a)(2), 1538(a)(1)(B)$.

15. For a general discussion of the tension between traditional rcclamation development and contemporary instream demands for water, see Lawrence J. MacDonnell, Managing Reclamation Facilities for Ecosystem Benefits, 67 U. CoLo. L. REv. 197 (1996). See also Melissa K. Estes, Comment, The Effect of the Federal Endangered Species Act on State Water Rights, 22 ENVTL. L. 1027 (1992). 
Supreme Court put it in another context, "[n]ot only are existing laws read into contracts in order to fix obligations as between the parties, but the reservation of essential attributes of sovereign power is also read into contracts as a postulate of the legal order." ${ }^{\prime 16}$ For example, a newly enacted fire safety code can mandate new construction by the owner of a rental property, even if the additional costs involved make the property uneconomic to operate. ${ }^{17}$

Are these the precedents upon which the Court would rely in analyzing a cutback in water deliveries, assuming that the cutback was only a moderate fraction of the total contractual amount (thus being outside the total-diminution-of-value-test of the Lucas $^{18}$ case)? Or would the Court see such cutbacks as a physical invasion, similar to the government expropriating a fraction of the acreage of a landowner's tract of land because it wanted a fire station or a park? Alternatively, might the Court find that the irrigator's property rights were qualified, $a b$ initio, by the usufructuary nature of water rights ${ }^{19}$ or by the proposition that no one can obtain a property right to denature a stream so as to exterminate one of its indigenous species. ${ }^{20}$ The U.S. Supreme Court, as presently constituted, has closely divided in its view of Fifth Amendment takings doctrine, ${ }^{21}$ and today no one can say with confidence how the Court would likely resolve some version of the hypothetical case I have posed. The one thing that can be said with confidence is that the federal government (and some elements of the property-rights community as well) has been reluctant to litigate such a case. ${ }^{22}$ During a congressional hearing, New Mexico's Senator

16. Home BIdg. \& Loan Ass'n v. Blaisdell, 290 U.S. 398, 435 (1934) (considering a mortgage moratorium law during the Depression that provided debtor relief); see also National R.R. Passenger Corp. v. Atchison, Topeka \& Santa Fe Ry. Co., 470 U.S. 451, 472 (1985).

17. See Queenside Hills Realty Co. v. Saxl, 328 U.S. 80, 83-84 (1946). But see Eastern Enterprises v. Apfel, 524 U.S. 498 (1998) (holding that an unfairly retroactive law was a taking of property).

18. Lucas v. South Carolina Coastal Council, 505 U.S. 1003, 1028 (1992) ("Where the State seeks to sustain regulation that deprives land of all economically beneficial use, we think it may resist compensation only if the logically antecedent inquiry into the nature of the owner's estate shows that the proscribed use interests were not part of his title to begin with.").

19. See Joseph L. Sax, Property Rights and the Economy of Nature: Understanding Lucas v. South Carolina Coastal Council, 45 STAN. L. REV. 1433 (1993); Joseph L. Sax, The Constitution, Property Rights, and the Future of Water Law, 61 U. CoLO. L. REv. 257 (1990).

20. The Court would presumabiy look to state law for a definition of the scope of the property right. See, e.g., National Audubon Soc'y v. Superior Ct., 658 P.2d 709 (Cal. 1983); Marks v. Whitney, 491 P.2d 374 (Cal. 1971).

21. See, e.g., City of Monterey v. Del Monte Dunes at Monterey, Ltd., 119 S. Ct. 1624 (1999) (54 decision); Dolan v. City of Tigard, 512 U.S. 374 (1994) (5-4 decision); Nollan v. California Coastal Comm'n, 483 U.S. 825 (1987) (5-4 decision).

22. At least one such case was pending at the time of this writing, in the summer of 1999: Tulare Lake Basin Water Storage Dist. v. United States, No. 98-101L (Ct. Cl. 1999). In United States v. Grants Pass Irrigation Dist., No. 98-3034 (D. Or. 1998), the court prohibited the District from diverting irrigation water to protect an endangered fish. Subsequently, the United States and the District 
Pete Domenici put it bluntly: "I do not know," he said, "whether we want them [irrigators in New Mexico] to go to court and see if they really have water rights under the Endangered Species Law. ${ }^{\text {"23 }}$ This statement suggests the accuracy of Interior Department Solicitor John Leshy's shrewd observation that sometimes law enforcement is best served not by clarity but by ambiguity. That is, uncertainty-a fear that the alternative could be worse-may be the incentive needed to bring all the relevant actors to the table in search of a mutually acceptable solution. It should be obvious at this point that the "takings" dilemma is just a doctrinal, legal setting in which a familiar fundamental question is posed: How does an established economy adapt to new values?

A second troublesome legal issue is raised by the recent Supreme Court decision in the Winstar ${ }^{24}$ case. The precedent provided by that case potentially subjects the United States to damages for breach of contract even in situations in which a cutback on water deliveries would not rise to a Fifth Amendment taking. ${ }^{25}$ Winstar was not a reclamation case or a water case at all, but rather arose out of the savings and loan debacle, and its applicability to environmental cases is far from clear. Because it generated five separate opinions, it is very difficult to know precisely what theory could be said to reflect the views of any five justices.

Nonetheless, there is a quite strong tone in some of the Winstar opinions to the effect that the United States ought to bear the cost of legislatively imposed inability to fulfill its previously inade contracts, in the absence of express prior arrangements to the contrary. ${ }^{26}$ Whatever its future, Winstar indisputably reflects a weakening of the preexisting doctrines of unmistakability and sovereign power that had previously insulated the United States from contractual liability when subsequent federal legislation of general applicability made performance by the federal government impossible. Tliough the Bureau of Reclamation has thus far fared quite well in its contract litigation in the Ninth Circuit, ${ }^{27}$ Winstar represents a real risk to the United States, especially where older, largely unqualified delivery provisions in reclamation contracts could be put in play.

reached a stipulated agreement that allowed the District to divert, subject to specified monitoring requirements (stipulated preliminary injunction).

23. Hearings before the Senate Committee on Appropriations, April 22, 1999, at 24 (transcript on file with author).

24. United States v. Winstar Corp., 518 U.S. 839 (1996).

25. See id.

26. See id. at 904-05.

27. See, e.g., O'Neill v. United States, 50 F.3d 677, 682-83 (9th Cir. 1995) (holding that the United States government was not liable for breach of contract where valid legislation prevented the government from delivering the contracted-for watcr); Peterson v. United States Dep't of the Interior, 899 F.2d 799, 802 (9th Cir. 1990) (upholding a ruling that neither the Due Process Clause nor the Takings Clause prevented Congress from limiting the volume of subsidized water that a Water District can deliver to leased lands under their preexisting contracts with the Bureau of Reclamation). 
In addition to the "takings" and contract issues, a federalism issue underlies ESA/water disputes. ${ }^{28}$ Section 8 of the Federal Reclamation Act $^{29}$ (which is involved in many ESA/water controversies) provides that conformity to state law is to control the administration of federal water projects. Nothing in the laws of most states appears to prevent diverters from dewatering a river in order to put its waters to other, out-of-stream beneficial uses..$^{30}$ Nor do most Bureau of Reclamation water permits authorize the use of the water for fish and wildlife purposes. ${ }^{31}$ If the claim that Congress did not niean for the ESA to displace or override state water law rules were to prevail, ${ }^{32}$ it would be necessary for the Bureau of Reclamation to seek state approval before it could allocate even its own water to instream fishprotection purposes to meet ESA requirements. In such a case, as we shall see, the state might be empowered to subordinate federal ESA enforcement to its own local economic interests. While no state could constitutionally veto ESA enforcement, the Court might hold that, before intruding on state water rights, federal authorities must return to Congress for enhanced authority to displace state-authorized water uses; or, alternatively, Congress might have to look to other solutions to the problem (for example, regulating fishing in the ocean, which is another source of pressure on ESA-listed anadromous fish).

The risks presented by potential litigation over the takings, contract, and federalism issues noted above, taken together with the risk of weakening amendments to the ESA, should make clear why the Department of

28. See United States v. Glenn-Colusa Irrigation Dist., 788 F. Supp. 1126, 1134 (E.D. Cal. 1992). National Marine Fisheries Service sought an injunction to curtail diversion of water for irrigation, and the court found that the ESA provides no exemption from compliance to persons possessing state water rights, and thus the District's water rights do not provide it with a special privilege to ignore the Endangered Species Act. See also Kristen Dorrity, Comment, Will Federal Environmental Regulation Be Permitted to Infringe on State Vested Water Rights?, 11 UCLA J. ENvTL. L. \& PoL'Y 113 (1992); Estes, supra note 15. See generally United States v. Albrecht, 496 F.2d 906, 911 (8th Cir. 1974) (holding that state law interpretation of an easement is not applied where it would subvert a federal program's goals).

29. Section 8 states, in part:

Nothing in this Act shall be construed as affecting or intended to affect or to in any way interfere with the laws of any State or Territory relating to the control, appropriation, use, or distribution of water used in irrigation, or any vested right acquired thereunder, and the Secretary of the Interior, in carrying out the provisions of this Act, shall proceed in conformity with such laws ....

43 U.S.C. $\$ 383$ (1998).

30. See generally Joseph L. SaX et al., Legal Control of Water Resources ch. 3 (3d ed. 2000).

31. But see Westlands Water Dist. v. Natural Resource Defense Council, 43 F.3d 457, 461 (9th Cir. 1994) (finding Reclamation held state permits for fish and wildlife propagation adequate to implement federal law requirement under the Central Valley Project Improvement Act's mandate).

32. As well it might under the Court's most recent interpretations of section 8 of the Reclamation Act. See California v. United States, 438 U.S. 645, 667 (1978) (holding that under the Reclamation Act of 1902, the Secretary of the Interior must follow state law regarding water rights and the condemnation of water rights). 
the Interior sought innovative, negotiated approaches to ESA compliance in western water cases. The approach adopted in the ESA water cases discussed below is thus suggestive of the likely shape of biodiversity policy in actual, on-the-ground practice in the next several decades.

\section{III \\ CAse STUdies}

\section{A. The Snake River ${ }^{33}$}

The Snake River in Idaho provides an illuminating case study because it reflects a situation of high sensitivity in terms of the rights of water users and of the role of the state vis-à-vis the United States. The problem arose out of the need for augmented flows to assist migration of endangered salmon smolts on their way to the ocean. The systemic issues presented by listed salmon in the Snake/Columbia River basin are massive, involving several states and a neighboring nation, as well as Indian tribal rights, ocean fisheries, hydropower production, fish hatcheries, land uses above the river, and a variety of federal and regional agencies and laws, of which the ESA is only one..$^{34}$ For purposes of this discussion, I have selected just one piece of this immense puzzle: water releases on the Snake River in Idaho that potentially affect agricultural irrigation in that state.

Since 1991, as a result of the Northwest Power Planning Council's Strategy for Salmon ${ }^{35}$ and the National Marine Fisheries Service biological opinion under the ESA, the Bureau of Reclamation has provided 427,000 acre-feet of water from a series of its Idaho reservoirs on the Middle and Upper Snake River above the Hells Canyon complex of Idaho Power Company dams (which block salmon migration in the Snake).$^{36}$ Fortunately, not all the available water in the reservoirs was contracted for. In most years, these reservoirs have some storage capacity that is not required to meet irrigation needs. So there was, in that sense, water available for release pursuant to the biological opinion.$^{37}$ The state of Idaho, however, took the position that such releases could be made only in conformity with

33. Much of the uncited information in this Part came from numerous telephone interviews during May and June 1999 with Duane Mecham, attorney, Office of the Solicitor, U.S. Dep't of the Interior.

34. The literature is extensive. See, e.g., Michael C. Blumm et al., Beyond the Parity Promise: Struggling to Save Columbia Basin Salmon in the Mid-1990s, 27 ENVTL. L. 21 (1997).

35. See 16 U.S.C. $\S 839$ (1994).

36. See John M. Volkman, A River in Common: The Columbia River, the Salmon Ecosystem AND Water Policy 24-41 (report to the Western Water Policy Review Advisory Comm'n, 1997).

37. In Carson-Truckee Water Conservancy Dist. v. Clark, 741 F.2d 257, 260 (9th Cir. 1984), the Court held that the Secretary had authority to allocate uncontracted water to endangered species purposes. 
state law..$^{38}$ Reclamation had appropriated the water pursuant to state law (the standard way of acquiring water to store in its reservoirs for subsequent delivery, pursuant to section 8 of the Reclamation Act) and its permits authorized storage and delivery of water for irrigation and municipal and industrial purposes. Fish and wildlife were not listed as a beneficial purpose. Both the state and local water users claimed that Reclamation could not use the stored water for purposes not identified on the water permits. The United States did not agree (thus putting in issue one of the knotty legal questions noted above).

One may ask why the state or water users should care about surplus water stored in a Reclamation reservoir to which they have no contractual rights, and which appears unnecessary to meet their contractual needs. The reasons are several. First, the states are determined to see that section 8 is followed in principle and that any uses conform to state law. Second, insofar as the state prefers irrigation or municipal use to fish preservation, it wants to make sure that water that would otherwise be available for future development is not previously committed to environmental uses.

This, by the way, is a familiar situation. Water users in the service area of federal reservoirs routinely hold to the view that any uncontractedfor water should remain available for their future needs because the reservoirs were authorized and built to serve them, and that the water should not be viewed as available to meet other federal purposes that might arise in the future (such as Indian tribal clamis as well as environmental demands). They also view water in storage in federal reservoirs as a reserve supply to meet the needs of contract users in the event of unusual drought conditions. As reservoirs are drawn down below the level necessary to provide required space for flood control purposes in order to provide fish flows, that reserve is dissipated. Finally, fish-need releases may not be congruent with hydropower production maximization. For all these reasons, even a system relatively rich in "excess" water may have trouble meeting downstream demands for fish-friendly flow augmentation.

In the Snake River case, negotiations between federal and state officials led to a series of short-term fixes. The Idaho legislature first enacted a three-year, temporary law applicable through 1995, authorizing limited use of storage water for flow augmentation. ${ }^{39}$ Reclamation proceeded in compliance with the Idaho statute, but was careful to make clear that it did so without prejudice to its legal position that it had authority to provide flow augmentation from its uncontracted water in storage without having to obtain state permission.

38. See Volkman, supra note 36, at 92; see also In re SRBA Case No. 39576, 996 P.2d 806 (Id. 2000) (U.S. may not appropriate under Idaho water law for instream flows).

39. See Act of March 30, 1992, No. 796, 1992 Idaho Sess. Laws 101, 101 (codified as amendments to Idaho Code $\S 42-1763$ ). 
However, Reclamation did not have enough assured uncontracted water in storage to meet its entire 427,000 acre-foot release commitment. ${ }^{40}$ It was thus presented with the unpleasant prospect of having to reduce deliveries to those with contract rights, which would almost certainly have generated litigation both over constitutional taking and contract right claims. To preempt this prospect, and without ceding any of the government's legal positions, Interior Secretary Bruce Babbitt made a commitment to purchase-on a willing-buyer, willing-seller basis-water needed for instream use over and above what was available in storage, to be released pursuant to applicable state law. ${ }^{41}$

As the 1995 teinporary state legislation approached expiration, the question of what to do next became more critical. Idaho was reluctant to renew the legislation for three primary reasons. First, it was uneasy about entering into any long-term arrangement for fear of creating a precedent in favor of flow-augmentation releases. Western water interests are always reluctant to set precedents (however nonbinding in a formal legal sense). This is not an unreasonable concern, since respect for existing uses-albeit nonbinding ones-has proven a very powerful influence in western water administration. ${ }^{42}$ Second, Idaho was dubious about the technical basis for the flow-augmentation requirements in the biological opinion and wanted to maintain as much incentive as possible to keep that determination open to reexamination. One way to do so was to avoid having a long-term commitment to providing the 427,000 acre-feet of instreain augmentation. Third, consideration was underway to make some structural changes, including possible removal of four Corps of Engineers dams on the Lower Snake River in Washington ${ }^{43}$ which would likely change the demands on other uses and users.

With a stalemate in the offing, Reclamation filed applications with the Idaho Department of Water Resources to amend its project water rights to include fish and wildlife inaintenance as one of the authorized purposes. Just as anticipated, numerous objections were filed, and the applications were set to go to full hearing. This was no doubt a calculated move on the federal side to create a mini-stalemate. In one sense Reclamation had subjected itself to a refusal on the part of the state authorities to expand the purposes of its project water rights, which would have intensified the

40. See Western States Water Council, supra note 12, at 6.

41. See id. It should be noted parenthetically that property owners are frequently almost as resistant to federal (compensated) exercise of eminent domain power as they are to imposition of uncompensated regulatory power.

42. See, e.g., Colorado v. New Mexico, 467 U.S. 310 (1984). This has been an issue on the Colorado River for many decades. See also Water Education Foundation, 75th ANNIVERSARY COLORAdo River COMPACT SYMposium ProceEdings (1997).

43. See Michael C. Blumm et al., Saving Snake River Water and Salmon Simultaneously: The Biological, Economic, and Legal Case for Breaching the Lower Snake River Dams, Lowering John Day Reservoir, and Restoring Natural River Flows, 28 ENvTL. L. 997 (1998). 
difficulty of meeting the requirements of the biological opinion. On the other hand, a rejection by the state would have created a crisis of federalism that would not have been attractive from the perspective of western water interests. In the context of the national politics of the ESA, the ability of irrigators in Idaho to prevent the United States from preserving salmon populations on an interstate river, even when it was willing to pay for the water it needed to do so, would surely have been perceived by many as overreaching state prerogatives. It would have produced precisely the sort of prosalmon crisis that would have been most attractive from the federal side. Not only would it have involved the charismatic salmon rather than snail darters or some other little-known creature, but it also would have suggested that the whole Pacific Northwest region was being held hostage by a cabal of Idaho farmers.

After extensive negotiation, another interim bill was enacted extending Reclamation's authority for flow augmentation through 1999, and then through $2000,{ }^{44}$ but the state held tightly to its authority. The result was to create a high probability that required instream flows would be available as needed, but without the state having made any significant concessions either as to permanence or as to its sovereign prerogatives. Specifically, Idaho agreed to let Reclamation lease water solely on a year-to-year basis, and only through the medium of state water banks (institutions that facilitate transactions among irrigators for leases and exchanges of water to cover agricultural surpluses and shortages) ${ }^{45}$ In this way, the state kept Reclamation on a tight rein. Under local water bank rules, water leased for instream purposes is subject to an agricultural preference (if a farmer needs it, he can bump Reclamation's lease right), and water leased for instream auginentation is treated as the last to fill the reservoir, meaning it would be the first to feel any shortage.

The next steps were left open. One may properly view all this as a subtle game of federal-state relations being played out where each party very carefully choreographs its moves with a larger strategy in mind. The state maintains the posture that it is sovereign over all uses of water within Idaho, keeping the feds at its door as supplicants, nnaking no long-term arrangements and maintaining inaximuin pressure to avoid committing significant amounts of water to instream flows, thus protecting Idaho's future development. On the federal side, the United States has obtained the water it needs and-one may say-pressed the state to do what has to be done to meet ESA federal law requirenents, like it or not. Second, and in the same sense, the United States got the Idaho legislature to act affirmatively twice to pass legislation at the behest of federal biodiversity needs.

44. See Idaho Code § 42-1763B, 2000 Idaho Sess. Laws, ch. 222, § 2, p. 616.

45. For a description of the functioning of the Upper Snake River water banks, see MacDonnell, supra note 15 , at 228 n.98. 
And, finally, it has now created a de facto precedent stretching for nine years, from 1991 to 2000, during which Idaho water users have allowed the full ESA-required quantum of water to go downstream for salmon protection purposes, and thus proven that such releases can be made without injury to Idaho interests. So, from the federal perspective, a useful precedent has been set: Instate diversionary needs can be met without jeopardizing listed species. Moreover, and most importantly, it has shifted the agenda of water managers. Everybody has been focused on getting water to the salmon. Traditional resource use has been reoriented (and yet maintained) and restoration of natural systems is underway on the Snake River. Practice has trumped theory.

\section{B. The Rio Grande and the Silvery Minnow ${ }^{46}$}

The Rio Grande presents a more troubled and troublesome case. ${ }^{47}$ For one thing, there is a lot less water to work with. Again, we have a species listed under the ESA, the silvery minnow. The river is fully appropriated in New Mexico and supplies have been so tight that parts of the minnow habitat dry up in the summer. In fact, in 1999 biologists went down to the remaining pools im that portion of the river that goes dry, scooped up netsfull of the still-living minnows there, and trucked them upstream to an area where water was flowing. ${ }^{48}$

The stretch of the river at issue is the Middle Rio Grande, 163 miles in New Mexico between Cochiti Dam, south of Santa Fe, and the headwaters of Elephant Butte reservoir in Socorro County. This is where most of New Mexico's share of the river, divided among the states of Colorado, New Mexico, and Texas, is used, and it also comprises the habitat of the silvery minnow.$^{49}$ Where does the water go? The great bulk of it is taken for irrigation, and a considerable amount is also taken up by exotic plants, primarily the water-loving salt cedar, that have invaded the banks of the river. As is often the case, the essential problem is viewed very differently by different constituencies. To the irrigation community, it is a zero-sum game. As one hydrologist put it, "[s]omebody's ox is going to get gored.... We don't have enough water to keep the river wet without

46. Much of the uncited information in this Part came from numerous telephone interviews during May and June 1999 with Tim Vollman, attorney, Office of the Solicitor, U.S. Dep't of the Interior.

47. See generally, ERnie Niem \& Tom McGuckin, Water Management Study: Upper Rio GrANDE BASIN (report to the Western Water Policy Review Advisory Comm'n, 1997).

48. See Rebecca Roybal, Rare Fish Run Out of Water, Albuquerque Journal, Apr. 26, 1999, at A1.

49. See U.S. Fish and Wildlife Service, Endangered and Threatened Wildlife and Plants, Final Rule to List the Rio Grande Silvery Minnow as an Endangered Species, 59 Fed. Reg. 36,988 (1994) (to be codified at 50 C.F.R. pt. 17). 
damaging somebody." 50 The Rio Grande's water was being used for farming before any thought was given to the river ecosystem. On the other side, environmental advocates see "the real issue as how do we use water efficiently and rationally to meet societal demands." 51

Thus far, there seems to be little will among the adversaries on the Middle Rio Grande to find common ground. ${ }^{52}$ In a hearing held in April 1999, speaking of this very setting, Interior Secretary Bruce Babbitt said, "I have never worked in an environment in which the natural resource users have been so rigid and inflexible; and I would say exactly the same thing of the environmental groups. Now, it is in that context that we must deal with this problem." 53 This is in sharp contrast to Idaho, where the contending parties genuinely wanted to find an accommodation so as to stave off both a biological and a legal crisis. Probably the main reason some parallel process has not yet occurred on the Rio Grande is that crisis has been averted thus far by a series of temporizing steps (but, in contrast to Idaho, without creating a framework that could sustain a mutually agreeable longer term solution).

Since the drought of 1996 , water has been obtained for the minnow from a supply stored, but not currently needed by, the City of Albuquerque. This water comes from the San Juan Chama project (imported from the San Juan River basin into the Rio Grande). The water is transported to Heron Reservoir in the Rio Grande basin and stored-if not needed-in Abiquiu Reservoir, a Corps of Engineers reservoir on the Rio Chama, a Rio Grande tributary. Previously, Albuquerque had released this water for irrigation use in the Middle Rio Grande Conservancy District, but more recently the city has made it available to meet the needs of the silvery minnow. In 1999 , of the 58,000 acre-feet of supplemental water that was found for the minnow, some 35,000 acre-feet came from Albuquerque's surplus. However, that water is neither sufficient in quantity nor provides a long term solution for the minnow, as it is slated for use by new development in Albuquerque. And while, in one sense, the outcone seems to be the same as on the Snake (a temporary supply of water for the fish), the crucial difference is that the stakeholders are not actively engaged in working together to fashion a solution, even a temporary one. They are just living off some temporary fat im the system..$^{54}$

50. Mike Taugher, Over-Demand Draining Rio Grande of Scarce Water, ALBUQUERQue JournAL, May 9, 1999, at B1 (quoting Steve Hansen).

51. Id. (quoting Kevin Bixby, director of the Southwest Environmental Center).

52. The contentious posture of the parties can be sensed from Maria O'Brien, Shortage and Tension on the Upper Río Grande: Protecting Endangered Species during Times of Drought, Comments from the Perspective of the Middle Rio Grande Conservancy District, 39 NAT. ResourCes J. 145 (1999).

53. Transcript of Hearings Before the Senate Committee on Appropriations, supra note 23, at 21.

54. Albuquerque has filed suit challenging the use of its imported water to meet ESA needs in the Rio Grande Basin. City of Albuquerque v. United States, No. Civ. $99-985$ (D. N.M. Sept. 1, 1999). 
Another difference is that from time to time there have been hints that water interests in New Mexico would like to foment test litigation over the reach of the ESA. A common perception among some opinion leaders that the silvery minnow is a "trash fish" may strengthen that inclination. For reasons noted above, the federal government has not wanted to go down the path of litigation..$^{5 s}$

There appear to be a number of possibilities for producing needed flows. ${ }^{56}$ Among the actions that have been proposed to ease the problem on the Middle Rio Grande are these:

1. Modernization of irrigation facilities should be undertaken. The Middle Rio Grande Conservancy District, which diverts nearly all of New Mexico's share of the river's water, has old-fashioned canals that are largely unlined, and does not account accurately for water used. It is claimed also that many of its farmers use excessive water because of lack of land leveling, which is causing wasteful pooling. In 1996, the Interstate Stream Engineer found that the District irrigates fewer acres than it did fifty years ago, and yet uses more water. Moreover, the Rio Grande is an unadjudicated stream, so rights to water have never been accurately determined and quantified.

To begin to deal with these issues requires both money and leadership. The State Engineer has seemed reluctant to go forward with adjudication, which would be an important step toward controlling irrigation use, though he has been taking steps to get irrigators to prove their needs. There are many long-standing water rights applications on which the state has never taken formal action, and requiring users to prove beneflcial use in order to get their water right approved will help to rationalize the system, though that effort is expected to take a few years. Some federal money might help modernize the system, but that would require the support of New Mexico's senior senator, Pete Domenici, who has thus far shown little interest in protecting the silvery minnow.

2. The Santa Ana Pueblo, which has significant resources as a result of its casino operations, has shown considerable initiative in phreatophyte eradication and, more generally, in improvement of habitat along its entire stretch of the Rio Grande, and appears to be

55. Environmental interests filed suit in November, 1999, and in the dry summer of 2000 the river was kept wet by continued temporary purchases of water under court supervision. Rio Grande Silvery Minnow, et al. v. Martinez, No. CIV 99-1320 JP/KBM-ACE (D. N.M.).

56. As Larry MacDonnell pointed out in his comprehensive study of opportunities for reclamation projects to adapt to contemporary demands for stream rewatering and restoration:

For example, installing an outlet works to allow releases of water in the winter months means

that reservoir water not previously released in this period will leave storage. Irrigators who

want water delivered to them during the summer might ask, "Whose water is being released?" Moreover, retrofitting existing facilities can be expensive. There is the very real issue of who should pay for these changes.

MaeDonnell, supra note 15 , at 219. 
interested in expanding its idea to a regional initiative. Senator Domenici has been supportive of that initiative.

3. Another step that has been proposed is modification of the operation of upstream Bureau of Reclamation reservoirs. Those reservoirs currently make releases in order to meet the state's obligations for deliveries to Texas. The claim is that water now released in the winter should instead be released during the spring or summer, to be more helpful to the minnow. However, summer releases would mean loss of more water to evaporation and thus less for delivery to Texas. The Rio Grande Compact Commission, which schedules releases, favors winter releases, even though the Fish and Wildlife Service has proposed rescheduling them for the spring.

4. It might also be possible for the Bureau to release some additional water from its upstream reservoirs to meet the needs of the minnow. The question here, as noted in the discussion of the Snake River, is determiming how much one should draw down reservoir storage. Under existing practices some water is held in storage against the prospect of low-flow years, as a sort of insurance policy for those who have entitlement to project water. As reservoirs are drawn down for other purposes (such as instream flow augmentation), the risk of having to "short" irrigators rises. ${ }^{57}$

5. Similarly, the United States could enter into willing-buyer agreements with irrigators to lease water as needed for ESA purposes, a version of what are generally known as dry year options (where farmers agree to rent part of their water on an as-needed basis for a fee). ${ }^{58}$

As this relatively long list of possibilities suggests, the situation on the Middle Rio Grande is by no means lacking in opportunities for rescue. One iunportant lesson of the silvery minnow case is that just because there are technically feasible solutions available does not mean that the path to reaching them will be smooth. It takes a very elaborate combination of factors to accommodate legal, political, economic, and diplomatic interests sufficiently to get the relevant stakeholders in a positive negotiating frame of mind. To take but one example, it may seem obvious to an outside observer that federal acquisition of dry year options would provide a quick fix. Sucli an approach seems to be similar to what the federal government did on the Upper Snake. But things are not nearly as straightforward as they seem. Neither cities nor farmers are eager to sell. Also, once the government becomes committed to a policy of buying water rights to meet ESA demands, which is not part of a more comprehensive program, it

57. See Elephant Butte Irrigation Dist. v. Dep't of the Interior, No. 90-95 (D. Utah 1992). In this case, the District claimed it was entitled to compensation for the value of stored water lost when releases are made for other purposes, such as species preservation, even when current contract deliveries are not affected.

58. See SAX ET AL., supra note 30, at 218-19. 
implicitly suggests unwillingness or inability to use regulatory authority to meet statutory imperatives. The United States does not wish to send either message, and as long as others are unwilling to make some commitments as well, the issue is likely to remain stalemated.

If the parties cannot find some mutually agreeable solution that avoids setting precedents neither side wants set, the likely alternative is litigation, and the shift of authority to a federal court, along the lines of the unhappy (if ultimately productive) model of the protracted spotted owl litigation. ${ }^{59}$ That would doubtless be the least attractive prospect to water users. A holding action, along the lines of the Idaho experience, is one possibility, at least in the short run. But there is also a far more attractive model, and that is the approach taken on the Platte River.

\section{The Platte River ${ }^{50}$}

If the Snake River case is a study in how to avoid failure, and the Middle Rio Grande a study in how to court it, the Platte is, by contrast, a case study in the possibility (though not the certainty) of success. ${ }^{61}$ It is perhaps the most encouraging model we have for the new biodiversity era. By all odds, the Platte should have been the most difficult of the three water/ESA disputes under consideration. It is a river with relatively little water in it, ${ }^{62}$ that has been extensively dammed, ${ }^{63}$ and that is diverted for intensive agriculture, power, and municipal use in three different states (Wyoming, Colorado, and Nebraska) who have been fighting with each other over water for nearly seventy years. Like other western rivers ${ }^{64}$ the Platte was developed for economic purposes long before anyone thought of protecting habitat or instream flows for fish or birds; and like New Mexico, each of the three states on the Platte long took the position that it had no water to spare from existing uses.

59. The history of the litigation is noted in Seattle Audubon Soc'y v. Moseley, 80 F.3d 1401 (9th Cir. 1996); Seattle Audubon Soc'y v. Espy, 998 F.2d 699 (9th Cir. 1993); and Seattle Audubon Soc'y v. Evans, 952 F.2d 297 (9th Cir. 1991).

60. Much of the uncited information in this Part came from numerous telephone interviews during May and June 1999 with Margot Zallen, attorney, Office of the Solicitor, U.S. Dep't of the Interior.

61. For background, see David H. Getches, Colorado River Governance: Sharing Federal Authority as an Incentive to Create a New Institution, 68 U. CoLo. L. REv. 573, 623-65 (1997).

62. Its current flow is about 1.3 million aere-feet (maf) per year-down from its virgin flow of 2.6 maf-compared to the Colorado's 14 maf and the Columbia's 150 maf. See Ray Ring, On One of the Most Spoken-For Rivers in the West, Environmentalists, Irrigators, and State and Federal Governments Thread Their Way Through a Tenuous Agreement, HiGH CounTRY NEws, Feb. 1, 1999 , at 1.

63. There are 15 major dams. See id.

64. For a detailed description of the Platte River controversy, see J. David Aiken, Balancing Endangered Species Protection and Irrigation Water Rights: The Platte River Cooperative Agreement, 3 Great Plains Nat. Resources J. 119 (1999). 
Yet, the states are now engaged in an experiment in regional cooperation and restoration of the Platte basin, which, though it has a long way to go and could still falter, is nonetheless remarkable for the creative steps it has taken. ${ }^{65}$ Before describing the positive accomplishments to date, it is inportant to emphasize that years of fruitless efforts were expended to develop a basin-wide solution to the River's problems. Margot Zallen, an attorney for the Interior Department who has long dealt with Platte River issues, put it succinctly, when asked how this negotiation finally turned the corner:

The right timing and a crisis for all parties is crucial.... Until water users in all states faced the real possibility that they each would have to implement measures that were far more onerous than they believed tolerable, there was no way to even start basin-wide negotiations. ... The ESA is the great convener and the great conciliator. Without the pressure induced by the potential power of the ESA, the states and [their] water users would have had no incentive to resolve the serious environmental issue of the degradation of the Central Platte. ${ }^{66}$

Why didn't the ESA function similarly as a catalyst on the Rio Grande or the Snake River, which presented similar issues? Why didn't the legal uncertainties described at the outset leave this controversy in something closer to the stalemate in New Mexico or the fragile and tentative accommodation that we saw in Idaho? There is no simple or obvious answer, but there are a few differences that may have been crucial. For one thing, on the Platte there was no possibility of simply continumg business as usual, even in the short term. The reason is that the Federal Energy Regulatory Commission hydropower license of the most important single facility in Nebraska, the Kingsley Dam, expired in 1987. Those who relied on the dam and the reservoir water stored behind it had to seek relicensing, and that proceeding raised ESA issues that had to be confronted. Critical habitat for four species, including the whooping crane, was located directly downstream of Kingsley Dam and the water it stored in Lake McConaughy, the largest surface storage facility in the basin ${ }^{67}$ Similarly, right-of-way permits of a number of diverters on national forest land in Colorado had come up for renewal. There, too, affirmative action was required, and ESA issues were also presented, which threatened those diverters' continuing ability to divert water from streams in the National

65. See id.

66. Margot Zallen, Integrating New Values With Old Uses in the Relicensing of Kingsley Dam and Related Facilities: Making Part of the Problem a Part of the Solution 17-18 (unpublished conference handbook, presented at Dams, Water and Power in the New West, Eighteenth Annual Summer Conference of the Natural Resources Law Center, School of Law University of Colorado, Boulder, June 2-4, 1997).

67. See Ring, supra note 62, at 14. 
Forests. ${ }^{68}$ Water users on the Platte probably felt, deep down, that they would ultimately have to make concessions to ESA requirements, whereas the users in Idaho and New Mexico likely felt that they would have a reasonable chance of prevailing in a legal showdown over the ESA, if it came to that. An irrigator with a water right and a contract feels a sense of propriety in a way that no mere permittee or licensee does.

A second difference may be attributable to the involvement of three different states, each of which was involved in its own controversies over ESA obligations. Because each was involved in independent proceedings, each risked being held responsible for a greater percentage contribution to the solution of the problem (which was focused on habitat in Nebraska downstream of all three); thus each had an interest in making sure that the other states bore their fair share of the burden. That competitive situation may have operated as an inducement to get together and to find a mutually acceptable solution. In such a setting, it can be hazardous not to play at all, while others are possibly agreeing to a deal that leaves the nonparticipant with a greater obligation. Paradoxically, the more extensive and multifaceted the problem, the greater the incentive inay be for some sort of cooperative action.

A third factor was the presence of a reopened interstate equitable apportionment case, Nebraska $v$. Wyoming, ${ }^{69}$ a 1945 decision of the U.S. Supreme Court in which Nebraska raised a claim that both Wyoming and Colorado should supply additional water for the downstream habitat. While the case is still to go to trial before the Special Master, in an interim ruling, the Court decided that evidence on environmental injury could be submitted. ${ }^{70}$ The ESA was thereby, at least indirectly, put into play in a forum that has undoubted authority to call each of the states to account. This prospect no doubt added to whatever other incentives the states may have felt to sit down at the table and cut as good a deal as they could on ESA responsibilities (though they continue to fight fiercely in the case itself).

Other factors were at work as well. Two of the three states had been involved in an ESA program on the Upper Colorado River that was having positive outcoines, and so they had some experience with a program that was working. ${ }^{71}$ They had tried recalcitrance (for example, working

68. See generally Wendy Weiss, The Federal Government's Pursuit of Instream Flow Water Rights, 1 WATER L. Rev. 151, 173-75 (1998); Thomas K. Snodgrass, Comment, Bypass Flow Requirements and the Question of Forest Service Authority, 70 U. Colo. L. Rev. 641 (1999).

69. 325 U.S. 589 (1945).

70. See Nebraska v. Wyoming, 515 U.S. 1 (1995).

71. Current participants in the program include Colorado, Utah, and Wyoming as well as water users associations, environmental organizations, and federal agencies. Among the elements of the program are state court approval of instream flows for irrigation season return flows, a Memorandum of Understanding between the U.S. Fish and Wildlife Service and the Colorado River Watcr Conservation District for reservoir releases to be made at the discretion of the Service up to a specified amount, and leases providing for delivery of water out of a Bureau of Reclamation Rcservoir. See 
politically to get the law weakened), and that strategy had failed. The Platte had been an exhausting battleground for many years, and the participants were no doubt weary of fighting and getting nowhere. Finally, high-level federal officials personally spent extraordimary amounts of time and effort on trying to get the Platte River negotiations on track. While each of the other cases discussed above has been reasonably high profile, none had the priority that the Department of Interior gave to the Platte, along with a few other of its highest-level agenda items, such as California's Bay-Delta, the Everglades, and the spotted owl controversy in the Pacific Northwest.

Thus, for a combination of reasons, the Platte River was ripe for serious negotiation, and it has produced an impressive plan for addressing ESA/biodiversity issues. One of the most important elements of the Platte negotiation is that the parties determined to get a program in motion at the earliest possible time, rather than sitting back and waiting for all the uncertainties to be resolved or even all the usual legal prerequisites to be completed. The plan is built upon a cooperative agreement that sets forth a first stage plan. That plan is provisional. It was developed prior to either the completion of the Environmental Impact Study under the National Environmental Policy Act (NEPA) with its preferred alternative or the completion of a fimal biological opinion. ${ }^{72}$

Of course, the United States did not sign the agreement at that stage and could not officially do so, but the hope and expectation was that the preferred alternative and the reasonable and prudent alternatives of the biological opinion would be close enougli to the plan under the cooperative agreement that existing momentum would be maintained. As to scientific uncertainty - and there is a good deal of it - the parties agreed to set aside fundamental conflicts about species needs, target flows, and even the Endangered Species Act itself, $\dot{m}$ order to make a plan that will reevaluate the science while beginning to take concrete steps that benefit habitat. As a public document with "Questions and Answers for the Platte River Recovery Program" puts it:

In embracing the Cooperative Agreement process, the participants have concluded that, whether or not they agree with the Fish and Wildlife Service, project-by-project litigation would be likely without a Program. Such litigation-particularly in opposition to a federal agency considered to have expertise-carries a risk that it will not be successful. The proposed Program also responds to new

Preliminary Draft Programmatic Biological Opinion for Recovery Program Actions and Water Depletions in the Upper Colorado River from Rifle, Colorado to Lake Powell 6-8 (Mar. 5, 1999) (typescript on file with author). Funding of the program ( $\$ 80$ million) is to be shared by the United States ( $\$ 46$ million), the three states ( $\$ 17$ million) and power revenues ( $\$ 17$ million). See id. at 13 .

72. See Aiken, supra note 64, at 144 n.148. The agreement and its appendices can be found at $<$ http://www.platteriver.org/library>. For additional information regarding implementation of the agreement, see <http://www.usbr.gov/platte>. 
information about the complex relationships among flow, habitat and species recovery. ${ }^{73}$

In the first stage of the plan-or "first increment" as it is called-each of the three states is to take steps that will increase or improve water flows. ${ }^{74}$ Each step is also designed to be minimally disruptive both to existing uses and to environmental values. The most creative of these is a scheme in Colorado whereby some 10,000 acre-feet of water per year is pumped during times of abundance and stored in pools in a state wildlife facility, and then permitted to seep back into the river for availability in the summer when it is most needed for ESA purposes. ${ }^{75}$ In Wyoming, a controversial new diversion project was tabled, and, in its place, Pathfinder Dam will be raised so as to increase its storage capacity. Sixty percent of that new storage, about 15,000 acre-feet per year, will be new water that can be released downstream for ESA purposes. The balance will be used to meet the purposes of the previously proposed Deer Creek project, which would liave diverted water to supply the City of Casper. ${ }^{76}$ In Nebraska, an agreement was reached to put ten percent of the water stored behind Kingsley Dam, some 50,000 to 70,000 acre-feet, in an environmental account, to be available for release as needed by the downstream habitat. The expectation is that the creation of this environmental account will not result in shortages to farmers who rely upon the stored water (or at least will not threaten shortages unless there is a historically unprecedented drought).

The three state projects will provide something like one-half of the new water that is in the first increment. Those projects are thus far the only ones firmly in place. In line with the sequential style of the plan, additional needed water is expected to be provided, at least in part, by water conservation projects and by acquisition of existing water rights on a willingbuyer, willing-seller basis. ${ }^{7}$ How exactly that will be accomplished remains to be determined. A consultant was hired to propose ideas for obtaining the 60,000 to 80,000 additional acre-feet of water that will be needed to implement the first increment of the plan.

The plan also calls for the acquisition of some 10,000 acres of land for habitat restoration purposes, and some of that habitat acquisition in Nebraska is already underway. Obviously, all these efforts call for substantial amounts of money. The proposed budget for the first increment period is $\$ 75$ million, of which $\$ 58$ million is cash and the rest is the contributed value of water projects. The costs are to be divided with the United

73. U.S. Dep't of the Interior, Questions and Answers for the Proposed Platte Recovery Program (1999) (unpublished typescript, on file with author).

74. See Aiken, supra note 64 , at 146.

75. See id. at 147 n. 165 .

76. See id. at 135.

77. See id. at 152. 
States paying one-half, Colorado and Nebraska each paying twenty percent, and Wyoming paying ten percent. Interestingly, the states have agreed to assume the entire ESA burden for their water users, though they may require the users to contribute to some extent (as Nebraska water districts are doing for habitat acquisition). The time scale for this first increment is ten to thirteen years. Eight or so years will be needed to get all the projects in place, and a few additional years will be needed to monitor and analyze the results. ${ }^{78}$ At that time, further coinmitinents inay be called for.

Is this enough, and is it soon enough? The answer is maybe. Another answer is that it is probably as much as could have been achieved through a negotiated settlement. At first, the environmental community thought it was plainly not enough, and they walked out of the negotiations. They later returned, however, and took their two seats on a governance committee formed to administer the plan. ${ }^{79}$ Some irrigators also opposed the plan, claiming they were not adequately consulted (water districts rather than individual irrigators participated in the negotiations) ${ }^{80}$

One's answer to the question of sufficiency depends in large part on how much importance is attached to getting programs of this type and magnitude underway, leaving to a later date the question whether the original commitments are sufficient. While the amounts of water that have been committed will likely ultimately prove less than fully adequate (early estimates were that some additional 427,000 acre-feet per year would be needed; the first increment plan will produce at most 130,000 to 150,000 acre-feet per year), ${ }^{81}$ and while participants are protected froin deinands for additional commitments during the first increment period, those concessions were deeined worthwhile simply to get such an ambitious program in motion and to get some benefits to the species in place without further delay.

Perhaps the cooperative program's most significant achievenent is that it is addressing a habitat restoration issue on a regional, watershed, interstate level, rather than on the incremental project-by-project basis that the ESA's consultation system conventionally produces. A plan is emerging that is of the same dimension as the problem, and that is itself an accomplishment. Equally remarkably, the plan now has the three states, and water users in those states, engaged in a process whose primary purpose is to fimd a way to achieve an environmental goal. Thus, the whole focus of water-basin planning has been reversed from what it previously was. All the parties have been brought to recognize that it is in their best interest to participate in a species-first agenda, rather than in an allocation

78. See id. at 145 n.151.

79. See Ring, supra note 62.

80. See id.

81. See Aiken, supra note 64 , at 148 . 
among users. A new mind-set appears to be emerging as an operative matter, a change that would be enormously difficult to mandate legally (one might say something parallel about the Snake River process on a much more limited and subtle scale). Moreover, the enterprise has been institutionalized in the form of a diverse governance committee (one member from the Fish and Wildlife Service, one from the Bureau of Reclamation, one each from the three states, one water user from each state, and two environmental organization members).

These organizational or structural changes themselves produce some important results. For example, Nebraska has previously not regulated pumpers of groundwater (unlike Colorado and Wyoming), but now the two upstream states have a common interest in seeing that efforts to improve downstream habitat are successful. Thus, they have a stake in encouraging Nebraska to move toward a more effective management of its groundwater so as not to undermine the joimt plan, the success of which is in each state's interest. Another innovative proposal, no doubt inspired by air pollution laws, requires that any new development that takes water out of the river be offset by a compensating augmentation project. ${ }^{82}$

The plan also contains an interesting financing arrangement. I mentioned earlier that government acquisition of water rights through purchase or leasing, while it might avoid a confrontation about property or contract rights claims in connection with the ESA, could also set a troublesome precedent. One element of the Platte River plan is designed to avoid setting such a precedent. The United States is to pay one-half the costs, with the rest divided among the states. ${ }^{83}$ Such an arrangement leaves the federal government free to take the position in ESA/water cases, and in similar situations, that while it could legally achieve all the law's mandated goals through regulation, it will not press the point so long as private users and local public entities are willing to share the cost of implementing a plan. Such a system creates flexibility and an incentive to participate, while not yielding on an important legal precedent as to ultimate responsibility. It permits accommodations to be made on a case by case basis, using uncertainty about ultimate responsibility creatively. The public share can be calculated to rise just enough to get the job done without undermining local economies, while blunting users' incentive to litigate property and contract claims.

It is also notable that the parties to the Platte River plan are not very tightly bound. For example, under any of a variety of circumstances one of the states can pull out from participation in the governance committee. ${ }^{84}$

82. See Ring, supra note 62. Such a project could involve purchasing an existing agricultural diversion and leaving the water in the river.

83. See id.

84. See Aiken, supra note 64 , at 146 n.159. 
Similarly, by contract an effort has been made to provide assurances against additional obligations being imposed on any of the states during the first incremental period. ${ }^{85}$ And, as noted, there is no commitment to produce even the amount of water required in the first increment plan (for example, no one knows if there will be willing sellers or money to buy water if there are such sellers).

On the surface, this seems to be a very "soft" approach indeed. Its force is subtle. If everything breaks apart, the whole ESA process will have to be started again, with all the risks that involves. Everyone understands that, though no one says it. Even more significantly, the idea is that once the enterprise is underway, and people are working together toward achieving habitat restoration and economy maintenance goals, they will get invested in those goals and will get committed to success. The gamble is that the process will create its own prohabitat inertia, just as the old systems had their proirrigation, prodevelopment inertia. This is also the strategy being used in the California Bay-Delta effort, under the label of staged implementation. Though the parties are left free to walk away, the idea is to invest them in the success of the project. ${ }^{86}$ An illustration of this phenomenon was described by an Interior Department representative who had just returned from an event commemorating the second year of a habitat conservation plan negotiated with a forest products company. He remarked:

I thought what an interesting contrast from 1990-in 1990 no one would have expected us to be standing shoulder to shoulder with an industrial timber corporation to hear them effusively describe all of the great things they are doing on the ground for listed species. ${ }^{87}$

\section{CONCLUSION}

The Platte, along with such efforts as those in the Upper and Lower Colorado Rivers, and the San Francisco Bay-Delta, illustrate how

85. Part IV.A of the Agreement provides, in part, that "for water related activities existing as of the effective date of the Cooperative Agreement, FWS intends that the reasonable and prudent alternative during the term of the Program shall be the activities carried out by or on behalf of those water related activities through the Program...." Aiken, supra note 64, at 144 n.148. Section IV(D) provides that the "DOI and the states intend that the Program will function as a reasonable and prudent alternative for so long as the Program is attaining its goals and milestones. Regulatory certainty for the first increment of the Program will depend on timely attainment of the first increment objectives ... as measured by the achievement of specific milestones." Id. This is an example of one Interior Department official's observation that "some of the concepts that arose in Section 10 are beginning to find their way into Section 7." E-mail from Sean Skaggs to Joseph Sax, Professor, School of Law, University of California, Berkeley (Boalt Hall) (May 28, 1999) (on file with author).

86. See David R.E. Aladjem, CALFED Issues Revised Phase II Report, CALIFornia Water LAw \& Policy 93, 94 (Feb. 1999). The document is CALFED Bay-Delta Program, Revised Phase II Report, Draft Programmatic EIS/EIR Technical Appendix (June 1999).

87. Email from Sean Skagg, supra note 85. 
biodiversity values are being integrated into established resource economies. Essentially the idea is (1) to try to bring users together for a negotiated solution, sometimes described as the partnership approach; (2) to do so on a biologically rational scale (by region or watershed); (3) to employ multispecies plans to try to get ahead of the sort of repeated crises that arise out of a sequence of isolated ESA consultations; (4) to build enough achievement into such a program that there is a cushion against future projects or activities, so that there is not a risk of a shutdown every time someone wants to do something; (5) to craft a road map so that everyone will know what sort of measures will be considered first if reinitiation of consultation is required (that is, in effect to anticipate future reasonable and prudent alternatives); (6) in line with the effort to create a cushion, to strive for recovery as the essence of a program, as opposed to simply avoiding jeopardy; and (7) to look for creative solutions that avoid the most intractable prospects (for example, trapping cowbirds that were preying on a listed species at a reservoir, thus increasing the surviving number of nesting pairs, as an alternative to drawing down the reservoir's water supply, cutting down quantities available for use in order to provide additional habitat).

As both the New Mexico and Idaho instances attest, these efforts are by no means easy to implement, even under the pressures that the ESA can bring to bear. But when one considers how extraordinary it is to transition at all from the established developmental eco-economy into an economy that seriously values biodiversity, the fact that any real headway can be made seems almost miraculous. Of course, as the preceding case instances reveal, we are progressing in the disorderly, untheoretic, pragmatic way that is characteristically American. Only time will tell how extensively, and how successfully, the efforts described here will be carried out. But if the notion of a worthy experiment means anything, surely this is it. 